JOSING: Journal of Nursing and Health

Volume 1, Nomor 1, Desember 2020

e-ISSN: $2745-7877$

p-ISSN: 2746-0851

DOI: https://doi.org/10.31539/josing.v1i1.1204

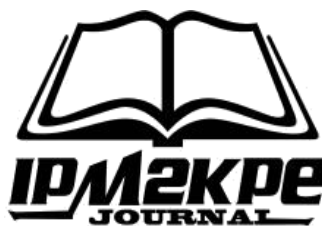

\title{
EDUCATION ABOUT EARLY ASKING AND BOUNDING INITIATIONS ATTACHMENT AGAINST THE MOTHER'S READINESS
}

\author{
Mera Delima ${ }^{1}$, Yessi Andriani ${ }^{2}$, Rahmatul Putri ${ }^{3}$ \\ Padang Pioneer College of Health Sciences ${ }^{1,2,3}$ \\ meradelima@rocketmail.com ${ }^{1}$
}

\begin{abstract}
The purpose of this study was to determine the effect of education about early breastfeeding initiation and bounding attachment on maternal readiness for the breastfeeding process at BPS Bunda Bukittinggi. This type of research uses the Preexperiment method with the design of one group pretest and posttest. In this study with the mean value of the readiness of mothers to breastfeed before doing education was 57,33 which then increased to 63,80 and the value of $p$ Value 0,000 ( $p<0.05$ ), meaning that there is an effect of education about the initiation of early breastfeeding and bounding attachment to maternal readiness for the breastfeeding process in the BPS Bunda Bukittinggi in 2019. It was concluded that education about early breastfeeding initiation and bounding attachment can increase knowledge in readiness for breastfeeding in pregnant women.
\end{abstract}

Keywords: Bounding Attachment Early, Breastfeeding Initiation, Maternal Readiness For Breastfeeding

\section{INTRODUCTION}

Breastfeeding is knowledge that is closely related to maintaining human life (Astuti, 2013). In order to have readiness in breastfeeding, supporting factors are needed that continually strive for breastfeeding success, which among others depends on the role performed by elements and factors such as the role of health workers, the role of the hospital and government, the physical role of the mother, family factors, and community factors and the presence of baby factors. One introduction to ASI is to carry out Early Breastfeeding Initiation (IMD) to newborn babies (Saleha, 2009).

According to 2013 UNICEF data the IMD rate in Indonesia during the IMD process is still relatively far compared to the prevalence of time in Southeast Asian Countries, such as in Thailand 50\%, and the Philippines 54\%, Myanmar 76\%. While based on data from the Ministry of Health of the Republic of Indonesia (2016) the coverage of exclusive breastfeeding in Indonesia which is less than one hour is $42.7 \%$, and in the province of West Sumatra is $(44.8 \%)$.

Early Breastfeeding Initiation is a process that is carried out in the first minutes of the birth of a baby where the baby looks for its own nipples. The influence of early breastfeeding initiation for babies is to be calmer, breathing and heart rate are more stable, this is due to the contact between the skin of the mother and baby (Mohctar, 2008).

The Early Breastfeeding Initiation has become the theme of the commemoration of the 2007 ASI World Week which is "Breastfeeding for the First Hour of Life followed by Exclusive Breastfeeding for 6 months, Saving more than 1 Million Babies". 
The benefits of this IMD are that it makes it easy for the baby to start the breastfeeding process and so that the baby is not confused looking for his mother's nipples when breastfeeding. Large opportunities can make mothers strengthen and continue breastfeeding activities for newborns until the age of 2 years, this can also increase the emergence of an inner bond between mother and child that creates love and caress (Bounding Attachment), this bond that is mutual love and need each other, so that knowledge is needed about the importance of IMD and bounding attachments, so that the readiness of mothers in breastfeeding babies can be carried out optimally (Bahiyatun, 2009).

Knowledge about newborn care in the community is still not optimally carried out such as a lack of knowledge to increase the growth and development of babies and adequate nutrition as well as improving the relationship between parents and babies. Especially in developing countries that still do not know about the proper way of babysitting and low socio-economic and education. The impact of the lack of knowledge and understanding of IMD and bounding attachment is that the baby is confused in finding the mother's nipples and does not get the necessary nutrients which colostrum in breast milk serves as a reduction in infant IMR because it contains protein and immunoglobulins as the body's defense for the baby. Efforts can be made to reduce infant mortality in Indonesia, one of which is by giving as soon as possible the existing colostrum in breast milk for newborns that is beneficial for increasing the body's immunity for infants, as well as by providing health education (education) about the importance of IMD and bounding attachment to mother or family.

Nurses have an important task in providing counseling in the form of health education, which is provided to pregnant women and families. Activities provided such as the introduction of the importance of IMD and bounding attachments that can make mothers have readiness to breastfeed their babies, health education is given to individuals, groups or communities to be able to know and apply this knowledge to improve behavior to a healthier life (Walsh, 2007).

BPS Bukittinggi Mother is one of the health service units in the city of Bukittinggi with the number of monthly visits of pregnant women 58 people, and trimester 3 pregnant women as many as 15 people. According to the Bukittinggi BPS Mother, the BPS Mother has not optimally done education about Early Breastfeeding Initiation (IMD) and bounding attachments. Initial interview conducted by researchers in March 2019 to pregnant women who were visiting BPS Bukittinggi Mother, 3 of them said they did not know the importance of the benefits of initiating breastfeeding and bounding attachments, and 1 pregnant woman said she did not know and never initiating early breastfeeding and bounding attachments at the time of the birth of her first child, the four pregnant women said they did not believe a newborn could find their own nipples.

The purpose of this study was to determine the effect of education about the initiation of early breastfeeding and bounding attachment to the readiness of mothers for breastfeeding at BPS Bunda Bukittinggi in 2019.

To find out the average maternal readiness for breastfeeding prior to the intervention of early breastfeeding initiation education and bounding attachments at BPS Bunda Bukittinggi 2019. To find out the average maternal readiness for breastfeeding after the intervention of early breastfeeding initiation education and bounding attachment at BPS Bunda Bukittinggi in 2019. To analyze the effect of 
education about the initiation of early breastfeeding and bounding attachments to the readiness of mothers for breastfeeding at BPS Bunda Bukittinggi in 2019.

The benefits of research for researchers are to increase the knowledge and understanding of researchers and as an application of knowledge gained during education as well as broaden the knowledge of researchers to know about the effect of education about the initiation of early breastfeeding and bounding attachments to the readiness of mothers for breastfeeding. It is hoped that educational institutions can provide benefits and can be used as input and scientific references in developing nursing knowledge, especially nursing meternitas to educate early breastfeeding initiation and bounding attachments so that maternal readiness for breastfeeding is carried out and become input for further researchers. And for BPS Bunda Bukittinggi can be input for health workers, professional organizations, especially related institutions in conducting early breastfeeding initiation education and bounding attachments, so that the achievement of health status can be increased to the maximum in providing quality health services for the community.

This study discusses the effect of education about the initiation of early breastfeeding and bounding attachments to the readiness of mothers for breastfeeding. Where the independent variable in this study is education about the initiation of early breastfeeding and bounding attachments and the dependent variable is the readiness of the mother for breastfeeding. The population in this study was 3rd trimester pregnant women who visited as many as 15 people at BPS Bunda Bukittinggi, the sample in this study were as many as 15 people using total sampling techniques. This research was conducted on July 1 - 15 of 2019 at BPS Bunda Bukittinggi, this research was conducted due to the lack of optimal knowledge of mothers about the importance of IMD and bounding attachments. This study uses a pre-experimental method with one group pre-post test design. The instrument used for data collection was a questionnaire.

Breastfeeding is a long-standing knowledge that has an important role in maintaining human life (Astuti, 2013). Exclusive breastfeeding is breastfeeding for 6 months without being mixed with other liquids such as formula milk, oranges, honey, tea, water and without the addition of solid foods such as bananas, papaya, team rice porridge. After 6 months of age the baby begins to be given complementary foods, while breast milk can be given up to 2 years or more (Maryunani, 2009).

The benefits obtained by breastfeeding for mothers according to Astuti (2013) are : Breastfeeding helps speed up the return of the uterus to its original shape and reduces bleeding after birth. Reducing expenses because breast milk does not need to be purchased. Breastfeeding can increase closeness between mother and baby. Babies who are often in the arms of a mother due to breastfeeding will feel the love of her mother. Breastfeeding reduces the risk of ovarian and premenopausal breast cancer, and heart disease in the mother.

Readiness for the process of breastfeeding in pregnant women is a condition that is owned by pregnant women in preparing themselves both mentally, and physically in the face of lactation since pregnancy. In this case, the breastfeeding process should be prepared well before giving birth. This is important so that the mother is truly prepared, both physically and mentally. This readiness will affect the quality and quantity of breast milk (Sriatin, 2017). 
Health education is a communication of information related to motivation, skills and confidence to take action to improve health that can be done in hospitals or in the community so that they can keep themselves healthier by avoiding bad habits and forming habits that benefit health (Nursalam, 2009).

The most important goal of health education is to achieve changes in the behavior of individuals, families and communities in fostering and maintaining healthy behaviors and healthy environments as well as playing an active role in efforts to realize optimal health degrees, the formation of healthy behaviors in individuals, family groups and communities in accordance with the concept of healthy living both physically, mentally and socially so as to reduce morbidity and mortality. The purpose of this education will be achieved optimally if it is supported by several things including competent human resources, good planning and adequate facilities. Planning in this educational process can be done by educators compiling a Counseling Event Unit (Indriyani, 2013).

Initiation of early breastfeeding is a period of learning to suckle in the first hour of a baby's life outside the womb, because this can prevent the baby from attacking various dangerous diseases in the most vulnerable periods in his life (Maryunani, 2009).

Bounding Attachment is a process between parents and infants who are constantly loving each other and giving both emotional fulfillment and need each other that begins with an inner bond and affection that can be closely related to the growth of healthy psychology and infant growth (Bahiyatun, 2009).

\section{RESEARCH METHODS}

This type of research is a pre-experimental research, with a one group pre-post test design design in which in this study the sample was interviewed first with a questionnaire measuring instrument (pretest) and then educated about IMD and bounding attachments and then conducted interviews again with a questionnaire measuring instrument (posttest), which aims to determine the effect education about IMD and bounding attachments to the readiness of mothers to breastfeed. Criteria for sample inclusion include: 3rd trimester pregnant women. Pregnant women who are willing to be respondents. Pregnant women who can read and write. Cooperative pregnant women.

Data were further analyzed using the average table before and after intervention was given for univariate data, while bivariate data using t-test (paired sample test), to see the significance of statistical calculations used a significance limit of 0.05 so that the value of $p \leq 0.05$ then the statistics are called "not meaningful". The study was conducted by referring to ethical principles, namely, self determination, anonymity, confidentially, and informed concent. 


\section{RESULTS}

\section{Univariate Analysis}

Table. 1

Average Readiness of Mothers for Breastfeeding Process Before Conducting Education About Early Breastfeeding Initiation and Bounding Attachments $19 \mathrm{n}=15$

\begin{tabular}{lcccc}
\hline \multicolumn{1}{c}{ Variabel } & Mean & SD & Minimum & Maximum \\
\hline $\begin{array}{l}\text { Mother's Readiness for } \\
\text { Breastfeeding Process Before } \\
\text { Intervention }\end{array}$ & 57,33 & 2,968 & 54 & 62 \\
\hline
\end{tabular}

Based on table 1 it is shown that the average readiness of mothers to breastfeed is 57.33, before conducted education about IMD and bounding attachments, at BPS Bunda Bukittinggi in 2019

Table. 2

Average of Mother's Readiness for Breastfeeding Process After Education Education on Early Breastfeeding Initiation and Bounding Attachment $n=15$

\begin{tabular}{lcccc}
\hline \multicolumn{1}{c}{ Variabel } & Mean & SD & Minimum & Maximum \\
\hline $\begin{array}{l}\text { Mother's Readiness for } \\
\text { Breastfeeding Process After } \\
\text { Intervention }\end{array}$ & 63,80 & 1,656 & 60 & 66 \\
\hline
\end{tabular}

Based on table 2 it is shown that the average readiness of mothers to breastfeed is 63.80, after educated about IMD and bounding attachments at BPS Bunda Bukittinggi 2019.

\section{Bivariate Analysis}

Table. 3

Average Increase in Mother's Readiness for Breastfeeding Process After being Educated About Early Initiation and Bounding Attachment $n=15$

\begin{tabular}{lllllll}
\hline \multicolumn{1}{c}{ Variabel } & Mean & SD & SE & \multicolumn{2}{c}{$95 \%$ CI } & \begin{tabular}{c} 
Sig p \\
\cline { 3 - 5 }
\end{tabular} \\
\cline { 4 - 6 } & & & Lower & Upper & \\
\hline $\begin{array}{l}\text { Average Increase in } \\
\begin{array}{l}\text { Mother's Readiness for } \\
\text { Breastfeeding }\end{array}\end{array}$ & 6.467 & 2.295 & 0.593 & 7.738 & 5.196 & 0,000 \\
\hline
\end{tabular}

Based on table 3 it can be explained that the mean value of increasing maternal readiness for breastfeeding after being given IMD education and 6,467 bounding attachments. 
Based on the results of the statistical test T test, $\alpha=0.05$ indicated that $\mathrm{p}$ Value $=$ 0,000 ( $\mathrm{p}<0.05$ ) which means the results of the paired test $<0.05$ then $\mathrm{H} 0=$ rejected means that there are differences in the readiness of mothers to breastfeed before and after IMD education and bounding attachments were conducted at BPS Bunda Bukittinggi in 2019.

\section{DISCUSSION}

\section{Univariate Analysis}

Readiness of mothers to breastfeed before an education about Early Breastfeeding Initiation and Bounding Attachment

From table 1 it is shown that the average readiness of mothers to breastfeed is 57.33, before doing education about IMD and bounding attachments, at BPS Mother Bukittinggi 2019. Breastfeeding is a long-standing knowledge that has an important role in maintaining human life (Astuti, 2013).

Yusnawati (2015) Readiness is a condition in which a person has reached a certain stage or connotes physical, psychological, spiritual and skill maturity. In accordance with theory Nursalam (2009) that education is a communication of information related to motivation, skills and confidence to take action to improve health that can be done in hospitals or in the community so that they can keep themselves healthier by avoiding bad habits and forming habits that benefit health, in providing maternal readiness to breastfeed can be given IMD education and bounding attachments.

Early Breastfeeding Initiation (IMD) is a baby that starts breastfeeding itself shortly after birth. The way the baby initiates breastfeeding early is called the breast crawl or crawl looking for breasts (Saleha, 2009).

Bounding Attachment is a process between parents and babies who are constantly loving each other and giving both emotional fulfillment and mutual need that begins with inner bonding and affection which can be closely related to the growth of healthy psychology and growth and development of infants (Bahiyatun, 2009).

This is also supported by the opinion of Sriatin (2017) Readiness for the process of breastfeeding in pregnant women is a condition that is owned by pregnant women in preparing themselves both mentally, and physically in facing the lactation period since pregnancy. In this case, the breastfeeding process should be prepared well before giving birth. This is important so that the mother is truly prepared, both physically and mentally. This readiness will affect the quality and quantity of breast milk.

This study is in line with research on the effect of early breastfeeding initiation education on the knowledge of third trimester pregnant women at the KIA Pertiwi Makassar Police. From the results of the univariate analysis of the study it was obtained that respondents' knowledge prior to health education showed that 6 people $(12.0 \%)$ had good knowledge, and 44 people $(88.0 \%)$ with less knowledge. Then the knowledge of respondents after health education showed that all respondents totaling 50 people $(100 \%)$ had good knowledge. This shows that health education can influence and enhance one's knowledge (Mahmud, 2013).

Based on the description above, the analysis of researchers that many mothers are still not ready to breastfeed, because they do not know whether the breastfeeding process should be prepared before the baby is born, so that in providing this education is needed, because readiness to breastfeed is a first step that must be owned by pregnant women so the creation of maternal readiness for the process of breastfeeding. 


\section{Readiness of Mothers to Breastfeed After an Education about Early Breastfeeding Initiation and Bounding Attachment}

Table 2 shows that the average readiness of mothers to breastfeed is 63.80 , after education about IMD and bounding attachments at BPS Bunda Bukittinggi 2019.

According to Slameto (2003) a condition is said to be ready at least including several aspects, there are three aspects that affect readiness, namely the condition (physical, mental, emotional), the needs or motives of goals, skills, knowledge and other understandings that have been learned.

This research is supported by research Rinata et al., (2015) about the preparation of exclusive breastfeeding for pregnant women in RB Eva Candi Sidoarjo, which shows that almost half that is $46.7 \%$ of pregnant women less preparing exclusive breastfeeding during pregnancy, $36.7 \%$ have done adequate preparation and only $16.7 \%$ were well prepared. This is because $30 \%$ of respondents have not tried to find exclusive breastfeeding information, $20 \%$ have not done breast care during pregnancy, $50 \%$ have not prepared nutrition for breastfeeding and 50\% have not prepared psychologically for breastfeeding. The conclusion of research on exclusive breastfeeding preparation for pregnant women is still lacking.

This is in accordance with the opinion of Maulana (2009) that health education is planned efforts to change the behavior of individuals, groups, families and communities that require a deep understanding, because it involves various terms or concepts such as changes in behavior and educational processes.

Utami (2008) argues that in this case, mother's knowledge is very closely related to the mother's attitude towards the initiation of early breastfeeding. Where if the mother's knowledge about breastfeeding is lacking, of course the mother's attitude can affect the implementation of early breastfeeding initiation. Though the impact of early breastfeeding initiation is very good, which can reduce morbidity and infant mortality and prevent post partum hemorrhage.

Based on the description above, the analysis of researchers is that education about IMD and bounding attachments can increase the readiness of mothers for breastfeeding, researchers argue that after providing education to respondents, means that something is received by the respondent and most pregnant women are of productive age and there are some who have college education, so that it is easier to understand the education provided by researchers, so as to increase knowledge in preparing the process for breastfeeding.

\section{Bivariate Analysis}

Increased maternal readiness for the breastfeeding process after being given education about the initiation of early breastfeeding and bounding attachments

Table 3 shows that the mean value of increased maternal readiness for breastfeeding after being given IMD education and bounding attachments was 6,467. Based on the results of the statistical test T test, $\alpha=0.05$ indicated that $p$ Value $=0,000$ ( $p<0.05$ ) which means the results of the paired test $<0.05$ then $\mathrm{H} 0=$ rejected means that there are differences in the readiness of mothers to breastfeed before and after IMD education and bounding attachments were conducted at BPS Bunda Bukittinggi in 2019.

Changes in maternal readiness for breastfeeding to respondents after education about IMD and bounding attachment according to the theory Notoatmodjo (2003) which explains that knowledge is one of the predisposing factors for behavioral formation, which in this case is in terms of making readiness for breastfeeding. 
This research is supported by theory Utami (2008) namely the implementation of IMD is the beginning of success in exclusive breastfeeding. IMD or Early Breastfeeding Initiation is breastfeeding for newborns by letting the baby look for her mother's nipples. This process is done by means of the baby placed on the mother's chest with the baby's skin attached to the mother's skin. How to breastfeed with Early Breastfeeding Initiation can train the motor children of children early and can prevent or reduce infant mortality and is also believed to help increase the baby's immune system against diseases that are at high risk of death such as nerve cancer, leukemia and psychological impact on the mother and baby

This is also consistent with the research of Ana, Eti (2018), showing good knowledge of 22 people (53\%), enough knowledge of 14 people (33\%) and less knowledge of 6 people (14\%). As for attitudes that have positive attitudes as many as 23 people $(55 \%)$ and negative attitudes as many as 19 people $(45 \%)$. The conclusion of this research shows that most respondents have good knowledge and positive attitude about Bounding Attachment. Recommendations for health services especially maternity nurses to be further improved in providing health education to postpartum mothers with primipara about Bounding Attachments during the hospital.

This is also in line with research Sukmawati et al., (2018) the results showed there were differences in the intervention group with the control group before and after the IMD intervention with $\mathrm{p}<0.05$ and there was an influence of education on mothers' knowledge and attitudes about IMD and there is an increase in knowledge and attitudes of pregnant women regarding IMD after education / counseling

So the analysis of researchers that education about IMD and bounding attachments is very useful and influential in increasing the readiness of mothers for breastfeeding because education about IMD and bounding attachments can change the mindset of respondents who were not ready to be ready to breastfeed, so the readiness of pregnant women to breastfeed his child later.

Based on the results of research found in the field, respondents who received education about IMD and bounding attachments proved to have increased knowledge. As was done to 15 respondents at BPS Bukittinggi Mother, the average value of mothers' readiness to breastfeed before educating about IMD and bounding attachments was 57.33, which then increased to 63.80 . This proves that the increase in maternal readiness to breastfeed after education about IMD and bounding attachments.

\section{CONCLUSION}

There is an increase in the readiness of mothers to breastfeed prematurely between before and after conducting counseling on early initiation of breastfeeding and sanitary napkins at BPS Bunda Bukittinggi 2019.

\section{SUGGESTION}

It is recommended to health workers to provide education when visiting antenatal to third trimester pregnant women about early breastfeeding initiation and bounding attachments. 


\section{REFERENCES}

Ana, F., \& Eti, S. (2018). Gambaran Pengetahuan dan Sikap Ibu Nifas tentang Bounding Attachment di Ruangan Seruni Rumah Sakit PMI Kota Bogor, 10(2), 23-30

Astuti, A. (2013). Determinan Pemberian ASI Ekslusif pada Ibu Menyusui. Jurnal Health Quality, 4(1), 1-76

Bahiyatun, B. (2009). Buku Ajar Asuhan Kebidanan Nifas Normal (Alfabeta). Jakarta: EGC

Indriyani, D. (2013). Keperawatan Meternitas pada Area Perawatan Antenatal. Yogyakarta: Graha Ilmu Kartini

Mahmud, S. (2013). Pengetahuan Ibu Hamil Trimester III di Puskesmas Lisu Kec. Tanete Riaja Kab. Barru, 2, 105-110

Maryunani, A. (2009). Asuhan pada Ibu dalam Masa Nifas (Postpartum ). Jakarta: TIM

Maulana, H. D. (2009). Promosi Kesehatan. Jakarta: EGC

Mohctar, M. (2008). Synopsis Obsetri. Jakarta: EGC

Notoatmodjo, N. (2003). Pendidikan dan Perilaku Kesehatan. Jakarta: Rineka Cipta

Nursalam, N. (2009). Pendidikan dalam Keperawatan. Jakarta: Salemba Medika

Rinata, E., Putri, H., \& Hamdi, S. (2015). Persiapan ASI Eksklusif Ibu Hamil di RB Eva Candi Sidoarjo, 1(4), 125-133

Saleha, S. (2009). Asuhan Kebidanan pada Masa Nifas. Jakarta: Salemba Medika

Slameto, S. (2003). Belajar dan Faktor-faktor yang Mempengaruhinya. Jakarta: Rineka Cipta

Sriatin, S. (2017). Hubungan Pengetahuan Ibu tentang Perawatan Payudara dengan Kesiapan Menghadapi Masa Laktasi pada Ibu Hamil di Puskesmas Ranomeeto Kabupaten Konawe Selatan

Sukmawati, S., \& Bustan, N. (2018). Pengaruh Edukasi terhadap Pengetahuan dan Sikap Ibu Hamil tentang Inisiasi Menyusui Dini (IMD) di Wilayah Kerja Puskesmas Parangloe Kabupaten Gowa, 1(1), 7-13

Utami, R. (2008). Inisiasi Menyusu Dini Plus Asi Eksklusif. Jakarta: Pustaka

Walsh, L. V. (2007). Midwifery: Community-Based Care during the Childbearing Year. Jakarta: EGC

Yusnawati, Y. (2015). Asuhan Kebidanan Nifas dan Menyusui. Yogyakarta: Pustaka Belajar 